\title{
On some Specimens of Birds from British North Borneo.*
}

\author{
By \\ Nagamichi Kuroda, D. Sc.
}

I have received a small but fine series of bird-skins collected by Mr. Seikichi Tanaka, M.O.S.J., in the British North Borneo. He has in the second time visited the island between the end of February and the end of October, 1981. The specimens, which I have referred to 25 forms, have been already noted in several periodicals by many authors; but I have been so much interested that it is very apt to list the binds here with some notes. Finally I must express my deepest thanks for Mr. Tanaka's kindness of giving me these skins.

\section{Family NECTARINIIDAE.}

1. Ethopyga siparaja siparaja (Rafles).

Acthopyga eupogon Cabanis, Mus. Hein., i.p. 180 (1850-Boneo). Aethopyga chalcopogon Reichenbach, Handb. Scans., P. 303, pl. 586, figs. 3982-3983 (1854-Borneo).

1 f ad., Tawao, 15. r. 1931 (no. 18s09). Wing 18.5; tail 37; tarsus 13.5; exposed culmen 15.5; entire culmen $18 \mathrm{~mm}$.

Messrs. Chasen \& Kloss (Bull. Raffles Mus., Singapore, no. 4, p. 103, 1930) have united eupogon from Borneo with typical siparaja from Sumatra.

2. Leptocoma jugularis ornata (Lesson).

1 of ad., Tawao, 24. v. 1981 (no. 18510). Wing 51.5; tail 84; tarsus 14; exposed culmen 15.5 ; entire culmen $18.5 \mathrm{~mm}$.

3. Anthreptes malacensis bornensis Riley.

Anthreptes malacensis rhodolaema Kuroda, Iori, iv, p. 2 (1925Tawao, British N. Borneo) (nec Shelby).

$8 \delta$ f (ad.) \& 2 q $q$ (ad.), Tawao, 1. \& 24. v. and 1. \& 3. vi. 1931 (nos. 13811-13815).

* Cf. "Tori," Vol. iv, no. 19, pp. 1-11 (23 April, 1925). 


\begin{tabular}{|c|c|c|c|c|c|c|}
\hline No. & Sex & Wing & Tail & Tarsus & $\begin{array}{l}\text { Exposed } \\
\text { culmen }\end{array}$ & $\begin{array}{l}\text { Entire } \\
\text { culmen }\end{array}$ \\
\hline 13812 & $\delta$ & 68 & 44.5 & 16.5 & 15.5 & $19 \mathrm{~mm}$. \\
\hline 13813 & $\hat{\sigma}$ & 66.5 & 46.5 & 16.5 & 16 & 18.5 \\
\hline 13814 & क & 68 & 46.5 & 17 & 16.5 & 19.5 \\
\hline 13811 & 우 & 63.5 & 42.5 & 16.5 & 15.5 & 18 \\
\hline 13815 & 우 & 64 & 41 & 16.5 & 16 & 18 \\
\hline
\end{tabular}

These examples are identical with the description given by Riley (Proe. Biol. Soc. Wash., vol. 33, p. 55, 1920-Sandakan, British N. Borneo).

Family ARTAMIDA.

4. Artamus leucorhynchos leucorhynchos (Linneus).

1 fad., Tawao, 13. iv. 1931 (no. 13808). Wing $138.5 \mathrm{~mm}$.

Family PYCNONOTIDA.

5. Egithina tiphia viridis (Bonaparte).

of f (ad.) \& 1 q (ad.), Tawao, 14. iv.-1. vi, 1931 (nos. 13797-13799).

Wing of 60,62 ; $q 60 \mathrm{~mm}$. Wing paler in $q$ and blacker in $\delta$.

\section{Family CAMPEPHAGIDAE.}

6. Lalage nigra schisticeps Neumann.

1 오 ad., Tawao, 21. iv. 1931 (no. 13796). Wing $91 \mathrm{~mm}$.

C. Chasen \& Kloss (t.c., p. 60).

\section{Family MUSCICAPIDÆ.}

7. Rhiphidura javanica longicauda Wallace.

$1 " z "=$ ? ?, Tawao, 1. v. 1931 (no. 13795). Wing 74.5; tail $85 \mathrm{~mm}$.

8. Pseudogerygone (or Gerygone?) sulphurea salvadorii (Büttikofer).

Gerygone salvadorii Büttikofer, Notes Leyden Mus., x.v, p. 174 (1893-Southern Borneo).

1 of ad. \& 1 q ad, Tawao, 24. vi. 1931 (nos. 13816, 13817). 


\begin{tabular}{|c|c|c|c|c|c|}
\hline Sex & Wing & Tail & & $\begin{array}{l}\text { Exposed } \\
\text { culmen }\end{array}$ & $\begin{array}{l}\text { Entire } \\
\text { culmen }\end{array}$ \\
\hline$\hat{\sigma}$ & 51 & 35 & 16 & $8+x$ & $\underset{10.5+x}{\operatorname{mm}}$ \\
\hline 우 & 49.5 & 32.5 & 16 & 9 & 11 \\
\hline
\end{tabular}

These two skins before me have the following wing formula: the and primary about equals to the secondaries in length, instead of the and primary longer than the secondaries as in the genus Gerygone; nostrils linear and shut in by a membrane; rictal bristles a few in number. From these characteristics, I have considered this to be a species belonging to the genus Psendogerygone rather than that of Gerygone. If my consideration is right then the bird is a species and not a subspecies of sulphurea ${ }^{12}$, but I have no specimens of the latter bird for comparison.

The present male specimen lacks the white lores and without an incomplete pectoral band. The white spot on the inner web of the three outer rectrices is well marked and it occurs on the fourth as a mere dot as stated by Mr. Riley. The female before me has indistinct greyish lores (not whitish) and with a faint indication of pectoral band which is widely separated on both sides of the breast. The both skins have greyish brown upper parts and clear sulphur yellow on the under side; the chin, vent, under tail-coverts, under wing-coverts, axillaries and edge of wing white, very faintly washed with yellowish.

In Borneo, it is hitherto known only from the southern parts (type locality) (Moulton'), Kina Balu, N. Borneo (Sharpe ${ }^{3)}$ ), and North-east coast of Dutch Borneo (Pulo Raboe Raboe and Pulo Samama-Riley ${ }^{4)}$ ), while the present specimens were obtained at Tawao in the British North

1) Robinson \& Kloss, Journ. Fed. Malay States Mus, viii, pp. 161-162 (1918).

2) Moulton, Guide Coll. Bornean Birds Sarawak Mus., p. 142 (1914).

3) Sharpe, Bornean Notes, Ibis, 1893, p. 561 (Kinokok, Kina Balu).

4) Riley, Proc. U. S. Nat. Mus., Vol. 77, Art. 12, p. 16 (1930).

5) Meise, Zur Systemaktik der Gattung Gerygone. Nov. Zool., xxxvi, pp. 371-373 (1931). 
Borneo. The occurrence of the bird in the locality perhaps shows the northern limit of the distribution of the species.

It should be noticed that Dr. Meise has rencently united salvadori, modiglianii, jacobsoni, etc. with sulphurea which has considered by him as a subspecies of fusca of Western Australia.

\section{Family SYLVIJDE.}

9. Orthotomus sepium cineraceus Blyth.

Orthotomus bomeonensis Salvadori, Uoc. Born., p. 247 (1874Borneo).

Orthotomus sepinm borneoensis Chasen \& Kloss, Bull. Rafles Mus., no. 4, p. 93 (1930-Sarawak and N. Borneo).

2 f d (ad.) \& 1 q ad., Tawao, 1. \& 24. vi. 1931 (nos. 13804-13806).

\begin{tabular}{|cc|c|c|c|c|}
\hline Sex & Wing & Tail & Tarsus & $\begin{array}{c}\text { Exposed } \\
\text { eulmen }\end{array}$ & $\begin{array}{c}\text { Entire } \\
\text { culmen }\end{array}$ \\
\hline$\hat{\sigma}$ & 46 & 40.5 & 18.5 & 15 & $17 \mathrm{~mm}$. \\
$\hat{\partial}$ & 46.5 & 40.5 & 19.5 & 15.5 & 17 \\
$\hat{+}$ & 41.5 & 35 & 18.5 & 13 & 16 \\
\hline
\end{tabular}

Messr's. Chasen \& Kloss (t.e.) consider that "adult males from Sarawak and North Borneo are perhaps rather purer grey above and have less white on the abdomen than cineracess Blyth, of the Malay Peninsula and Sumatra but we have only maintained borneoensis after a certain amount of hesitation."

The two males in this collection show that one specimen has very dark abdomen as Chasen \& Kloss considered, while another male has a large amount of white on the central parts of lower breast and abdomen! These two males were collected in the same month. From the above examples I am inclined to think that boneonensis (not bonneoeneis) seems to be a synonym of cinercceus rather than that of a valid race.

10. Orthotomus ruficeps sericeus Temminck.

1 tad., Tawao, 1. v. 1931 (no. 13807). Wing 54; tail 46; tarsus 23; exposed culmen 16.5 ; entire culmen $20 \mathrm{~mm}$. 


\section{Family TURDIDE.}

11. Copsychus saularis niger Wardlaw Ramsay.

Copsychus saularis amoenus Kuroda, Tori, iv, no. 19, p. 6 (1955) (nec Horsfield).

18 ad. \& 1 qad., Tawao, 5. and 6. v. 1931 (nos. 13800,18801 ).

Wing of 116, $q 103$; tail $\delta 103.5$, $q 88$; tarsus o 32.5 , $q 29$; entire culmen of (damaged), $q 25 \mathrm{~mm}$.

This pair of the form have entirely black rectrices without any white bases. Tho plumage of these birds has a bad smell as in Tubinares.

Messrs. Chasen \& Kloss have very well demonstrated on and recognized the six forms of Copsychus saularis from the Malay Peninsula and Sumatra (musicus), West Java (javensis). East Java and Bali (amoenus), East Borneo (pluto), North Borneo (niger), South Sarawak and West Borneo (problematicus) (Bull. Raffles Mus., no. 4, pp. $8 \pm-90$ ).

12. Kittacincla stricklandi stricklandi (Motlcy \& Dillwyn).

1 dad. \& 1 ㅇ ad., Tawao, 1. \& 6. v. 1931 (nos. 13802, 18803).

Wing of 94.5, ㅇ 84; tail o 118, ㅇ 81; tarsus of 26.5, $q 25$; exposed culmen $\delta$ (damaged), $q$ 1t; entire culmen $\delta$ (damaged), \& $19 \mathrm{~mm}$.

Messis. Chasen \& Kloss (t.c.) have mentioned that the length of wing and tail as follows:

\begin{tabular}{|c|c|c|c|}
\hline Sex & Locality & Wing & Tail \\
\hline 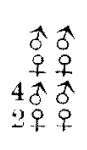 & $\begin{array}{l}\text { Mainland of Borneo } \\
\quad " \Rightarrow " \text { " } \\
\text { Islands of Borneo } \\
\text { Banguey }\end{array}$ & $\begin{array}{l}93-102 \\
92-95 \\
96-106 \\
94-95\end{array}$ & $\begin{array}{l}105 \mathrm{~m} \\
105-136 \\
100-108 \\
11=-14 \% \\
102-105\end{array}$ \\
\hline
\end{tabular}

Sharpe (Cat. B. Brit. Mus., vii, p. 89,1883 ) gives the measurements of a specimen (q) from Labuan as: wing $3.6 \mathrm{in} .=92 \mathrm{~mm}$; tail $3 . \mathrm{s}$ in $=$ $96.5 \mathrm{~mm}$.

From the above measurements it is clear that my of slin is une of the smallest birds from the mainland of Borneo and a $q$ before me is the 
smallest of all! Sharpe (t. c.) states that "four centre tail-feathers black, the rest pure white, with a slight blackish mark near the base of the inner web, increasing towards the outermost". But my specimens having these patterns are very different and the three outer tail-feathers are all entirely white.

\section{Family ALCEDINIDA.}

13. Halcyon chloris cyanescens (Oberholser).

1 ㅇa, \& 1 ㅇ subad, Tavao, 1. v. 1931 (nos. 13790, 13791).

\begin{tabular}{|c|c|c|c|c|c|c|}
\hline \multicolumn{1}{|c|}{ Sex } & Wing & Tail & Tarsus & $\begin{array}{c}\text { Exposed } \\
\text { culmen }\end{array}$ & $\begin{array}{c}\text { Entire } \\
\text { culmen }\end{array}$ & $\begin{array}{c}\text { Bill from } \\
\text { gape }\end{array}$ \\
\hline Pad. & 105.5 & 67 & 15.5 & 45 & 50.5 & 59.5 \\
Psubad. & 108.5 & 68 & 15 & 47.5 & 51 & 59.5 \\
\hline
\end{tabular}

Family PICID E.

11. Dryobates nanus aurantiiventris (Salvalori).

Yungipicts picotus Kuroda, Tori, iv, no. 19, p. 7 (1925). Cf.

Chasen \& Kloss, Bull. Raffles Mus, no. 4, p. 38 (1930).

1 9 (imm.?), Tawao, 1. v. 1981 (no. 13792). Wing 78; tail 34; tarsus 15.5: exposed culmen 14; entire culmen $15.5 \mathrm{~mm}$.

Dr. Stresemann has kindly informed me that "Yungipicus picatus is certainly nothing else than an individual variety of the common $Y$. conicapillus aurantiventris (in litt., 10 Sept. 1925).

A specimen before me have also a brown crown without any ashy grey wash on top of head. Possibly it is an immature bird as it has considered by Mr. Kloss ( $t$. c.).

15. Meiglyptes tukki tukki (Lesson).

1 of ad., Tawao, 6. v. 1931 (no. 18793). Wing $101.5 \mathrm{~mm}$.

16. Dryocopus javensis javensis (Horsfield).

1 ㅇ ad., Tawao, 24. v. 1931 (no. 13794). Wing $223 \mathrm{~mm}$. 


\section{Family FALCONIDA.}

17. Haliastur indus intermedius Gurney \& Blyth.

1 ad., Tawao, 16. viii. 1931 (no. 13674). Wing $361 \mathrm{~mm}$.

16. Accipiter virgatus gularis (Temminck \& Schlegel).

1 jux., Tawao, 16. x. 1931 (no. 18818). Wing $187 \mathrm{~mm}$.

I have another skin of this form from Cheribon, West Java (16. $\mathrm{x}$. 1930). These are no doubt autumn migrants from the north.

Fanily ARDEIDA.

19. Butorides striatus javanicus (Horsfield).

1 qad. (breed pl.), Tawao, 15. viii. 1931 (no. 13673). Wing 167; tail 60; tarsus 45; exposed culmen $61 \mathrm{~mm}$.

\section{Family COLLMBIDA.}

20. Streptopelia chinensis inornata (Bonaparte).

18 ad., Tawao, 16. x. 1931 (no. 13789). Wing 141.5; tail 133.5; tarsus 23.5; exposeed culmen $14.5+\mathrm{x} \mathrm{mm}$.

$$
\text { Family RALLID } A \text {. }
$$

\section{Hypotaenidia striata gularis (Horsfield).}

1 ad., Tawao, 8. vii. 1931 (no. 13787). Wing 113; tail 37.5; tarsus 35.5; exposed culmen $31.5 \mathrm{~mm}$.

The lower throat and chest are very dark as in the Philippine skins. The subspecific difference between siriata and gularis is rery doubtful.

22. Amaurornis phoenicura javanica (Horsfield).

1 f ad., Tawao, 15. viii. 1931 (no. 13788). Wing $134 \mathrm{~mm}$.

Family PHASIANIDE.

23. Rollulus roulroul (Scopoli).

1 dad., near Tawao, 28 x. 1931 (no. 13786). Wing $139 \mathrm{~mm}$. 
24. Lobiophasis bulweri Sharpe.

1 đad., Tawao, 25. ii. 1931 (no. 136r2). Wing 247; tail (stretched) 436; tarsus 39 ; exposed culmen 35.5 ; bill from nostril $20 \mathrm{~mm}$.

25. Argusianus argus grayi (Elliot).

1 d ad. \& 1 q ad., near Tawao, 18. x. 1981 (no. 13670, 13671).

\begin{tabular}{|c|c|c|c|c|c|c|}
\hline Sex & $\begin{array}{c}\text { Wing } \\
\text { to end of } \\
\text { secondaries }\end{array}$ & $\begin{array}{c}\text { Wing } \\
\text { to end of } \\
\text { primaries }\end{array}$ & Tail & Tarsus & $\begin{array}{c}\text { Exposed } \\
\text { culmen }\end{array}$ & $\begin{array}{c}\text { Bill from } \\
\text { nostril }\end{array}$ \\
$\hat{\sigma}$ & 775 & 440 & 860 & 103 & 37.5 & $19 \mathrm{~mm}$. \\
$\mathcal{F}$ & 325 & 286 & $208+\mathrm{x}$ & 86 & 81 & 14.5 \\
\hline
\end{tabular}

Ogilvie-Grant (Cat. B. Brit. Mus., xxii, pp. 365-366) has given the measurements of a pair of this form as follows:

\begin{tabular}{|c|c|cc|c|}
\hline Sex & $\begin{array}{c}\text { Wing to end } \\
\text { of secondaries }\end{array}$ & $\begin{array}{c}\text { Wing to end } \\
\text { of primaries }\end{array}$ & Tail & Tarsus \\
\hline$\sigma$ & 840 & 432 & 1067 & $101 \mathrm{~mm}$. \\
\hline & 356 & 320 & 300 & 91 \\
\hline
\end{tabular}

From the above measurements it is clear that my specimens are smaller in size than the measurements given by O.-Grant. 